\title{
Voices of Leadership
}

\author{
Donald G. DiPaolo \\ School of Education \\ University of Michigan \\ Ann Arbor, Michigan \\ dipper@umich.edu
}

\begin{abstract}
This study examines the impact of a leadership education retreat through the eyes of six undergraduate college men who participated in The Institute for Men of Principle at a midwestern college. What influences shape their definition and experience of leadership? Entry and exit interviews were conducted along with field notes from observations during the five-day curriculum. The study finds that early socialization experiences are paramount. In addition, participants uniformly struggle with acquiring and keeping the role of leader. Being a leader also plays a crucial role in the self-esteem of the participants. Analysis of the curriculum reveals that the application of leadership theory during hands-on activities was effective in shaping their views Framing leadership as a team endeavor and the need for personal congruence as a leader were the strongest consistent changes in participants' perceptions. The case is made for qualitative and longitudinal investigation for assessing leadership education programs.
\end{abstract}

\section{Voices of Leadership}

While browsing the local bookstore or contemplating job-related seminars, we are bombarded with information on leadership and leadership education. The concept of leadership has worked its way into local school districts and is a burgeoning phenomenon on college campuses. While some believe that leadership training is nothing more than a popular fad, lacking theoretical grounding and sound empirical support, leadership education appears more prevalent than ever. There are societal and cultural factors that are probably contributing to the phenomenon. Burkhardt and Zimmerman-Oster (2000) claim that "the American public perceives a crisis of leadership in our nation" --a perceived crisis that has spawned programs and initiatives at all levels of education (Burkhardt \& ZimmermanOster, 2000, p. 2).

Despite the preponderance of the emerging field and countless leadership education offerings, we know very little about the influences that shape one's image of self as "leader" and even less about the impact of the efforts to teach leadership. While there is growing consensus in the literature and in practice about what current programs should look like, there appear to be two areas in the research on leadership education where there are obvious gaps. The first problem 
with leadership education is that there has been little assessment of the initiatives. Many recent researchers have been calling for large-scale studies into the impact of this type of curriculum on students. We don't know what is really happening in these programs, especially with college students (Brungardt, 1996; Buckner \& Williams, 1995, p. 20).

Second, in addition to this lack of assessment, many researchers are beginning to question the type of assessments being used and the information they yield. What little qualitative inquiry does happen is usually in the form of brief surveys with no interviews. These questionnaires tell us some things about the impact of the experience: changes in willingness to lead, understanding the basic concepts of leadership, growing clarity of personal mission. However, we are learning little of the rich and complex experiences that shape a student's image of self as a leader over time. What we are getting, if anything at all, is assessment which is a brief snapshot of students' views that provides superficial assessment and begs exploration of a deeper picture (DePree, 1992; Lowe \& Gardner, 2001; Rost \& Barker, 2000; Wheatley, 1990).

In recent years the second gap is beginning to get attention as researchers investigate the nebulous areas of self-knowledge and self-leadership. What is going on in the inner world of these student leaders? Are they bringing a myriad of personal or psychological factors to the table which shapes their leading regardless of or in spite of the educational programming? What are the deeper motivations that propel students to lead and how does that interact with the curriculum? (Borwick, 1995, p. 112; Cashman, 1999; Chemers, 1993; Cox \& Cooper, 1989; Hartman \& Harris, 1992; Klonsky, 1987; Lowe \& Gardner, 2001; Sosik, 2000; Zacharatos, Barling, \& Kelloway, 2000).

In this paper I offer an in-depth look at how six male college students relate to their role as leaders and the key life influences that shape these perceptions. By conducting extensive entry and exit interviews and following the participants through a leadership education institute, I aim to advance new understandings of the impact and efficacy of this experience on the participants. The questions I explore are: What are their definitions of leadership? What motivates them to lead? What is their image of self as leader? How effective of a leader do they believe themselves to be? How willing are they to engage in leadership? What fears do they have in leading? What do they hope to gain by being a leader? By asking these questions before and after The Institute, we learn about leadership and leadership education through a unique, personal, and more complex lens. In addition, this work provides a framework for continued investigation into this little-understood phenomenon.

\section{Method}

College men from the U.S. and Canada have participated in The Institute for Men of Principle on a midwestern campus since 1999. Each summer undergraduate 
members of the host fraternity gather for sessions of this leadership training institute. Each session runs for five days and includes about 60 participants.

Participants are selected to attend in a variety of ways. For the most part, the process is one of self-selection. The Institute is advertised in mailings, a website, and in personal recruitment efforts, and up to three members per chapter/college are allowed to attend one of three sessions. For those who do not self-select, these participants are often recruited by local alumni, former participants who currently are leaders within chapters, staff members of the fraternity, and university greek affairs personnel who are aware of The Institute. Usually, the undergraduate has shown some leadership potential by holding an office in a chapter or on campus and they seek to accentuate their skills and abilities.

After permission was granted by the host fraternity to use the 2001 Institute as a site for research, I sent out an invitation to all students scheduled to attend, introducing myself and briefly describing the aim of my study--to garner their thoughts about leadership before and after The Institute. I also spelled out the requirements of participating, which essentially included agreeing to arrive early and stay late so as to be able to participate in entry and exit interviews.

It is important to note here the limited sample that my participants represent. All six college students are white, male, and already identified as leaders and are in leadership roles. They are not fresh to the conversation on leadership and some have had leadership training experiences in the past. These factors limit the scope and generalizability of the study.

\section{Participants}

Of the 60 registered participants, six responded that they would like to be in the research, which was the sample size I was intending. The low response rate was surprising and could limit findings. Most of the students were involved in preparations to take final exams when they received the invitation, which would have reduced their willingness to participate in the research. Arrangements were made for each of the six participants to arrive the night before the start of The Institute. The interviews were conducted at the international headquarters of the fraternity. This allowed for a quiet setting and privacy that was conducive for audio-recording. These six pre-experience or entry interviews were conducted in the afternoon and evening and lasted from 45 to 75 minutes each. Each participant signed a consent form allowing for the taping of the interview and for the use of their actual names in all parts of this paper and any subsequent publications.

\section{The Institute}

The Institute emphasizes the five fundamental practices of exemplary leadership presented by Kouzes and Posner (1995) in "The Leadership Challenge": 
Challenge the Process, Inspire a Shared Vision, Enable Others to Act, Model the Way, and Encourage the Heart. The Institute is designed so that there are large group sessions and small group sessions rotated throughout. Each participant is assigned a "chapter" and stays with that small group through the programming. With permission from the facilitators and clarity about my role as observer, I was assigned to Chapter One.

Knowing that my research would be enhanced by following the participants I had interviewed, I had asked that those who were participating in the study be put into the same small group. Five of the six were in Chapter One. One member was not because he was from the same university as another participant in this study, and the facilitators separate participants from the same university.

\section{Data Collection}

I observed participants through almost the entire five-day Institute. The only time I was not present was during one morning session when I was reviewing the entry interviews. I took extensive notes, which I recorded in a field note journal. Some examples of these would include descriptions of the activities, comments from the participants which related to issues raised in the entry interviews, and personal reflections on group dynamics. I was careful throughout not to interfere in the dynamics of the activities, though I certainly sensed on the first day or two that they were sensitive to being observed.

After The Institute concluded I conducted four exit interviews, once again recorded off campus at the fraternity's headquarters. The final two interviews were conducted the following week. One was done in person in my office at The University of Michigan, and the other was an arranged phone interview.

\section{Results}

What follows are six cases that highlight the coherence of experience the participants had around the themes that emerged in the interviews. In presenting, I do little interpretation. After presenting the cases, I report a cross-case analysis drawing similarities and differences.

\section{Themes}

Before presenting the case study analyses, it is important to understand the emergent themes that cut across the experiences of the program's participants which shed light on the impact of the leadership education experience as well as the nature of leadership itself. Among the six participants, four clear themes emerge. The influence of early socialization on their image of what a "leader" is and does is paramount. Within this context, family dynamics, religion, key role models, and athletics were unanimously mentioned. The second theme deals with the acquisition and congruence of the role of leader on the participant. Issues of 
power and control were evident as the participants reflected on performing the tasks of leading. Finally, being a leader clearly had a personal/psychological benefit for all involved.

\section{Case Studies}

Brad

Growing up as a twin was the defining relationship of Brad's life. He remembers from his earliest days the desire to compete with and beat his twin brother. This is a competitive dynamic that is intact even to this day. While acknowledging that his parents and religious upbringing helped him learn "right from wrong," Brad very much sees his relationship with his brother as foremost in shaping his leadership abilities and traits.

Brad has a strong, physical presence that dominates the room. He and his twin enjoyed a stint as Abercrombie and Fitch models. Blessed with an amazingly deep voice, a large build, and athletic prowess, these fed his instincts to lead and helped him establish and maintain his leadership position within his peer group of high school and college men. He knows he has a charisma that stands him apart. However, he also knows his leadership is not grounded in something deeper and in interviews relates that he fears losing the special status he now enjoys. "I wish leadership was this little glowing ball that I can ingest so I know that I have it."

At a very early age everyone called Brad a leader, but he was very confused as to why. Convinced there is "something very superficial about being a leader," he's always felt a bit uneasy with the label. Brad sees this label as a gift, but stresses that it is not useful unless he learns how to use it. Although he cites famous athletes and coaches as models, he really looks to himself as a model of leadership. One problem with this highly independent model is that he states, "It's like I have a machete and I'm blazing a path and everyone's following... but I have no direction." In addition he states, "making the right decision rarely enters my mind."

Brad knows that he has "it" but is unsure what that is. He sees himself in a precarious position because if his leadership is based on good looks, physical presence, his voice, and good grades, he understands that he may not always have these. On some level, Brad knows his leadership is superficial and that this can hide many failures. He approached The Institute in the hopes that it "doesn't all collapse."

The personal ego benefit for Brad really comes from the competing and winning. Brad has always wanted to be "the one." Being up front was the key, whether it was basketball practice or riding bikes in the neighborhood. Feeling sorry for "weak people," Brad insists that although he always leads, he doesn't intimidate and models behaviors that are critical to the success of his team. Whether it is 
"egotistical or selfish" Brad willingly takes advantage of power that comes with the spoils of the surface features of leaders. During the Board of Directors activity participants are asked to list the key role models and mentoring influences in their life and sit them in appropriate place on their Board. The first to offer a response to the small group, he quickly asserted, "I sit at the head of my Board."

Influence of the Institute. The most important activity for Brad during The Institute was the low ropes course. Blindfolded by the facilitator for "being a little too much of a leader," he was forced to rely totally on others for the success of his team. It showed him that he "can't get the job done by himself."

Brad realized after participating in The Institute that the sports model of leadership that he had been operating under actually was "oppressing others." He related that former Chicago Bulls coach Phil Jackson was able to make the Bulls champions once he got Michael Jordan to realize this same lesson. This awareness early in the program opened Brad's eyes to other ways of leading and framing leadership. He began to see leadership as a relationship among people where communication and mutual encouragement and effort led to success--for the individual, the team, and the organization.

The greatest impact the overall program had on Brad was his new awareness that leadership is not superficial but values-based. This epiphany came when the participants analyzed their ritual in the organization's private ritual hall. He said it was a "spiritual experience" where his inner and outer came together. He realized that if he led from core basic principles he was on solid ground regardless of how many followers he had. Convinced that you "got to be principled before you lead," he stated that connecting his actions as a leader with deeper principles is where real leadership lies.

Tyler

Anderson Island, Washington is where it all began. Saying, "It was like Lord of the Flies," Tyler learned that there were those who were a "cut above" and that he was one of them. Those early days laid the groundwork for success throughout his schooling years. Having a mom as a buddy and a dad as a role model were critical in his image of leadership and represents some of the ambivalence with which he holds the definition.

Tyler's father is a "self-made man" who had a vision for what family and home would look like on Anderson Island. Modeling self-sacrifice, hard work, and integrity, he also poses a bit of tension for Tyler because "we are exactly alike." His parents pushed him to be like Harry Leons, a local athlete who went on to play professional football. Tyler remembers being in the stands and hoping someday to be like Harry, who was his model of the ideal leader--smart, humble, successful, athletic, and well-rounded. 
Tyler, indeed, did grow up to become like Harry. As Valedictorian, accomplished pianist, and quarterback of the football team, he displayed the same grit and determination that his dad and Harry showed.

His mom in many ways provided a balance in his quest for leadership. His competitive nature is mellowed by his ability to listen and embrace others of all backgrounds. "I exude understanding." Tyler wants a balanced and successful life. His role models are models of success. Blending the roles of his parents with the example of Harry Leons gives him the ego identity he seeks.

He is very willing to be a leader and says it is a "great feeling being trusted to lead right." Tyler is very careful to make sure that he arises naturally to a position of leadership. "I want to show who I am and be selected by the group before I take over." Once selected, it frees him up to do the leading.

Tyler is conflicted about the power and influence that comes from leading. The most vivid example is his relationship with his little brother. Frustrated that his brother rejected his leadership, Tyler continued to try and lead him. By coming down on him "like a father" he realizes that he hurt the situation and was personally hurt in return.

Influence of the Institute. The curricular impact for Tyler was in some ways just "giving names to things I already knew." He had a clearer vision of leadership and was more motivated to engage in leading because "I know what I’m doing now." Tyler remained conflicted and curious about the role of his personal ego. " I have low ego needs, which is good, but I need to get more of a...fire. I am still me, but I'm going to explore different styles because it's so necessary to be a successful leader." He also realized he needs to encourage people more and help them see "your vision" once he's arisen to a leadership position. This reminded me of his struggles to lead his brother.

Tyler related that he now sees that "leadership is not a competition." In addition he had less fear in leading because he knows the psychology, styles, and change theory more and has picked up more tools and skills. He also benefited from seeing different styles being effective in leading others, but insisted, "I still have to be me."

Dan

"Never being satisfied" is one way that Dan frames his perspective on leadership. Perhaps this is best related to his use of leadership as a way out of a troubled and difficult childhood, which included the use of drugs. Dan's early socialization clearly laid the groundwork for his vision of leadership, his need for leadership, and his struggle with leadership. A gregarious, engaging, verbal young man, I was caught off-guard towards the end of the exit interview when he related the turning point in his life. Feeling "very alone," Dan attempted suicide at age 14. 
After this he threw himself into church leadership training and a host of school activities, including athletics, student government, and theater.

Dan's grandfather was his hero. He was a military general and a great leader, but most importantly he was loved by the people above and below him. Dan sees this affection as critical in being a leader. His brother was a leader but lost the respect and affection from those he led, and this remains a fear and caution for Dan today. His brother's loss of affection from his followers represents the conflict in Dan taking on the role of leader. He is petrified of losing "it". "Owning leadership means you could lose it." Dan related, "My greatest fear is being alone at the top as a leader and a person."

Dan would rather see himself as a humble servant, yet he has always struggled with managing his draw to the limelight with his inner desire to be "backstage." In a sense, being backstage doesn't fill the more compelling need he has to lead. Issues of power and control operate for Dan in service of his needs being met. Being able to be "a Nazi or a loving leader" depending on the situation, Dan is able to take on powerful positions in a variety of settings. He related several times that he is afraid when he leads, but is strongly drawn to do so anyway.

Dan expressed deep disappointment on the "superficiality of leadership." He was jealous of Brad (participant reported earlier) being anointed a leader just because he was tall, good-looking, and well built. He was surprised that others automatically followed Brad, and disappointed in himself for doing the same. Although he found out that the trust people had in Brad was well deserved, it gave him great pause.

The personal and psychological benefits in being a leader are clear with Dan. One of the most obvious examples is when he started what was eventually known as the "Fat Kids Club" at college. For oversized kids just trying to feel better about themselves, Dan saw a lot of personal benefit in the support he received there.

Influence of the Institute. The biggest impact of The Institute for Dan was that he had others he could call on for support. He realized that in employing a different leadership style in which he wasn't leading alone allowed him to have less fear in leading. Stating "true leadership is earned" Dan was encouraged to do more "inner work first" and become a better and stronger person. He would do this by examining himself and the ritual and principles to which he has pledged himself. While still reluctant to fully accept the label of "leader" because of his fears, he realized that "want(ing) to serve is enough" and "I don't always have to lead."

The Human Knot activity and Common Currency activities showed him that "communication is the key" to understanding each other and to leading effectively. In each, he saw how trial and error at talking your way through a difficult group task was the only way of accomplishing it. Finally, he realized that 
leading others and "motivating people towards a common goal made things better for others, and for me."

Mike

The foundation of Mike's view of leadership was shaped by two key events in his young life. At age two his father, a successful psychiatrist, was involved in a major car crash. In seventh grade he returned home from school to find out his parents were divorcing and he would be changing all his classes in school the next day. This was the beginning of Mike's inner and outer search to make sense of his world--one he did by embracing a view of himself as leader. Identifying with Conan and "having no fear of pain," Mike set out on an independent journey and "learned to depend on myself." Claiming "sports helped me to cope," Mike's self esteem was built initially through great success in sports. As a captain in athletics and current college football player, he carries a strong presence in a room.

Far from falling into the persona of "jock" Mike is amazingly giving and balanced. When speaking with him it is clear that he is a confident, charismatic, and verbal leader. Claiming he "always wanted a brother" and that "all of his friends were girls," Mike exudes a caring and engaging side. Mike credits his emergence as a leader to his leadership education teacher in high school. Spokane (WA) schools has a program which nurtures leaders and offers academic credit for courses. Mike took five straight leadership courses in high school.

In many ways, Mike now emulates his teacher. He defines leadership as "putting your words and morals into action" and is proud of his ability to stand up and take a risk. He loves learning about people and traces this to his classes and to the discussion about divorce in bible and circle talks at his high school youth group. His leadership teacher, "a second mom to him" adopted a troubled kid and was a model of giving to others, even through the death of her own husband. This relationship has paid off for Mike. Involved in community service organized by the coach of his college football team, Mike has "adopted" a three-year-old named "Carlos." Carlos "kept all the pain inside." One of Mike's proudest moments was when he had earned the trust of his young companion who finally opened up and cried.

Mike willingly accepted the mantel of leadership that came his way as he developed athletically, socially, and academically. Being amazingly wellgrounded, Mike states, "This is how I think and feel. I know who I am." Having "Catholic morals" and being willing to "stand alone for righteousness," he acknowledges that leading is sometimes a difficult thing. Mike is estranged from his older sister, who had a baby out of wedlock and "compromised everything I stand for." This continues to be an issue in the family. "Do I go tooth for tooth or turn the other cheek with my sister?" Mike's high ground sometimes leaves him standing alone, something with which he is very comfortable. "I am willing to be criticized." He is aware that his stances and "pushing hard" can lead to rejection. 
He also wonders if this plays a part in his lack of intimacy, "I've never had a serious relationship."

Mike's view of the power dynamic in leadership is based on his belief that he stands by the principles and values he believes in and works to help organizations do the same. Although he was the participant I did not follow in small group, it was apparent in my contacts with him that he is fiercely loyal and sure of himself, and unabashedly leads. Mike makes sense of his world by identifying with nobler notions of people and organizations. With almost romantic devotion, he commits to ideas and others. "The feeling I get from being a leader is great. I am dedicated to caring." Speaking of his leadership teacher he states, "I also realized that I learned to be just like her."

Influence of the Institute. There are some interesting parallels when we look at his caring for others, especially "Carlos." Carlos lost his father at almost the exact same age that Mike's father was injured. Indeed, after The Institute he stated, "I think I know why I help Carlos." The Institute and interviewing had another impact on Mike. He stated that he needs "to reassess his relationship with his sister and parents." Inspired by the many self-reflection and self-inventory activities to do inner work, he came to the realization that shutting off others "is affecting me."

Mike learned that "leadership includes the evolution of the followers." This is a basic tenet of the transformational leadership theories now so dominant in the field. He also asserts, "I used to tell. Now, I must show. I need to experience with them and encourage the heart."

One thing that reassured Mike is that "I found out that I have zero conflicts--total congruence with the principles of (my fraternity)." A new fear that emerged for Mike was the "purity of ideas being destroyed." In a sense this supports his pattern of deep devotion to his core beliefs. I don't want "evil to beat purity" was his way of framing those who unfairly attack the educational initiatives of his fraternity. Offering that "Christ laid down his life for his brother," you can see how he identifies with a role of service to others. After all, he states, "(Our fraternity) fills a hole--like religion."

The only person to talk about new fear after The Institute, he observes, "It is scary we bonded so closely, so quickly." Perhaps what scared Mike is the intimacy he enjoyed as it calls into question his independence. Mike's basic view of himself as solo brave leader still stands, but he is much more aware of others in the equation.

Nick

Nick's view of a leader as being the "number one servant" comes from his active and hard-working parents. Having a father as a high school principal, Nick learned to "get the job done." "I learned at an early age that I wasn't going to be 
the quarterback, so I looked for what I could excel at." Saying that leaders are "born with it" he is forever hesitant to take on the role and not sure if it applies to him. Noting the superficiality of being a leader, he tries to make up for what he thinks he lacks in surface traits. As an athlete, choir leader, and student council president, Nick concedes that leaders "do stick out." A "good talker" and "influential" guy, he says he leads out of necessity.

Being a product of "conservative Christian values" he says he wants to be an example to others. By being "first a follower" and then a leader he tries to avoid claiming leadership. One reason is that leaders often become cocky and lose their followers and when he tries to lead, "I do worse and can become overbearing." Nick cites a quote from University of Tennessee coach Phil Fulmer as a great ethic by which to lead. "It's amazing how much we can get done when nobody is worried about getting the credit." This is a trait modeled by his parents and his high school football coach.

Nick assumes leadership positions when he sees a job that needs to get done. Once leading, he does want to succeed. "Who doesn't strive for the perfect season?" This plays out in his conflict over just being the servant and giving to a group and his need to "win." I was surprised by the aggressiveness of his comment, "I want to be feared by other fraternities."

The power and control associated with being a leader is also an ambivalent fit for Nick. While leading he is "stubborn as a mule" and fearless in his loyalty to a position or organization, yet he tries to avoid the appearance of strong ego gratification. On many occasions I saw Nick vacillating between strong leading and passive following.

The main personal benefit for Nick in being a leader is that he gets to contribute to organizations and causes in which he believes, yet gets to do so in a way that appears humble and ethical. All the while, he is able to meet his need for recognition for "getting the job done."

Influence of the Institute. The main impact of The Institute for Nick was his awareness that "everyone is born with leadership qualities and that the best leaders are just right for the situation." He also was very proud to find out that he has integrity and that "superficial features don't matter much." He found out that he is true to his core. On the ropes course and during the Human Knot activity he learned humility and the importance of communicating with others. This was particularly important for him because he used to force his way once in a leadership position. Now he believes he has "less fear of failure because failure is less likely and easier to take when you are on a team." He is convinced that because of The Institute he will go to others for more help.

The other key is his new awareness of the importance of self-knowledge and the importance of self-knowledge for an organization. Those one-on-one connections 
emerge naturally and then leadership roles emerge. Upon reflection he recognized that he was most successful in leading when he took the time to really get to know where others were coming from and established a relationship with them.

\section{Kevin}

Kevin's early socialization has everything to do with what he believes a leader to be and do. The son of "parents who are great leaders" Kevin learned that "we all can be leaders in all phases of our life." Believing that leaders "take charge, set goals, and are respected," Kevin certainly does all three. He also emphatically states that "leaders handle stress and keep a balanced lifestyle--mind, body, and spirit."

Kevin admits to frequently being stressed, but he is "driven to compete." Citing a commitment to God and his parents, he wants to "leave my mark--leave my legacy." He learned in church group that the purpose of leading is to help a larger group, in that case, to "get the word of God out." He also knows that it is crucial to lead by example. As a captain of a sports team in high school and the president of his fraternity in college, he notes that he can be" impatient and pushy, but...he delegates well."

Much like the other participants in the study, Kevin recognizes that he fears failure. He also knows that to succeed you have to have good people around you. Kevin acquires leadership positions by vocalizing what he believes a group should do and then setting out a clear agenda for how he will accomplish the goals. This has been evident in his rising to the top of virtually every organization to which he belongs.

Influence of the Institute. The main impact of The Institute on Kevin was reconnecting with himself and with his mission of serving others. Citing in the exit interview that "Jesus was the ultimate servant," Kevin remembered that his parents have always encouraged him to change the world or improve aspects of the lives of others. After The Institute he proclaimed, "I am my chapter's master servant." This reconnection with servant also played out in the power dynamics of the role of leader. "It's not about leading in my direction, but our direction." Whereas before he was not too concerned about eliciting great input from followers, now he is convinced of the importance of this. "I need to listen more" and I want to "make a more personal connection with each member of my chapter. I don't do that." "I need to communicate my ideas to others and recognize their great personal qualities." These are important qualities for the "supreme leader of the house." "We need to connect on mutual values, not the superficial stuff."

The setting of The Institute, being separated and isolated, was helpful for him. Kevin was determined to slow down and attach greater meaning to things and was sure that his girlfriend would see the difference in him. The space to be pensive 
and reflective also affirmed for him that "I am a man of integrity." Because he saw the benefit in clarifying his inner beliefs, he wanted the same for members in his organization and the organization itself. "I wasn't balanced when I came here. This kind of self-discovery and reflection was lacking in my life. I've been baptized in (my fraternity's) blood."

\section{Cross Case Analysis}

Returning to the emergent themes, the data show the paramount importance of early socialization on the way each participant views leadership. All six men had key role models from whom they received a blueprint of what a leader is and does. For Brad it was the athletic competition with his twin. For Tyler, it was the well-rounded athlete Harry Leons, Jr. Dan had his beloved grandfather. Nick and Kevin mentioned their parents, and Mike had his leadership teacher in high school. In each, the family dynamics helped shape their leadership role. The curriculum didn't really uncover much of this, but it came out in the interviews. This finding supports the notions of Borwick (1995) and Chemers (1993) noted earlier who call for a closer look into the deeper motivations and personal family dynamics of leaders.

Each participant was very aware of how he gained his status as a leader. Some were very careful to earn the label first while others simply took charge. In any case, they all were able to take an objective look at whether or not the label was a good fit for them. Kevin, Brad, and Mike eagerly assumed the role with vigor, rarely looking back. Nick, Tyler, and Dan rose to leadership but in a more careful, measured way--each with some ambivalence.

Closely related to the above, the emergent theme of power and control played itself out in interesting ways. Each participant was very sensitive to this issue, especially at the end of The Institute. Brad, Mike, and Kevin originally had a view of themselves as leaders wielding significant power and influence. Each was accustomed to this being an authoritarian or solitary role. Whereas Tyler, Dan, and Nick all saw leaders as powerful, from the beginning they were much more aware of the team and community nature of leadership. By the end, all six participants viewed leadership as a group process and a sharing of influence rather than a heroic or dictatorial act.

I have earlier made the case that being a leader served some personal/ psychological purpose for each participant. For Brad, his self-esteem was fed when he led. "When I'm not leading, I just feel horrible about myself." For Kevin, his image as a good man is sustained by leading. This is supported by his references to Jesus and the Christian example encouraged at home. For Tyler, he is drawn to be the balanced man that is admired and respected. By garnering the support of his followers first and leading in so many ways (musical, academic, athletic) he feels good about measuring up to the role models in his young life. The most obvious personal benefit, perhaps, was with Dan. So fearful of never 
being alone, his multiple leadership activities keep him connected to and nurtured by others. For Mike, being a strong and independent leader that is fiercely loyal to a belief system or organization allows him to care for others and himself in ways for which he may have always longed.

There were two consistent themes that emerged from analyzing the impact of the curriculum on the participants--leadership is done on and by a team, and leadership is done best when the actions of the leader are rooted in a core belief system. These match the transformational and values-based leadership paradigm (Lowe and Gardner, 2001, (Bass, 1990; Burns, 1978; Kouzes \& Posner, 1995). Every participant spoke at length about not leading alone after they had completed the program. The concept of transformational leadership was quite evident in that all had a new realization that the act of leading must edify the leader, the follower, and the organization. In order to do this, a respectful relationship built on good communication and mutual trust must exist first. Every participant in some way related that The Institute gave them an opportunity to clarify what their deeplyheld values are and that a leader must lead with integrity to those values. Each of the six men left feeling more confident in themselves as a leader because their actions as leaders would now be grounded in something that could not be shaken by fad or resistance.

\section{Conclusion}

This study suggests that there is much to learn from a deep, rich, qualitative investigation into the early socialization, motivations, and key life experiences of the students we are teaching to be leaders. Each participant through the lens of fears, family dynamics, and personal models filters the curriculum. The complexity of the experience of leadership for the student is difficult to measure or uncover, but this is exactly what we must do if we are to come to greater understandings of the leadership education phenomenon.

If we are to assess more accurately what is going on in leadership education this study suggests that we must undertake the arduous task of going into the personal stories and narratives of students. This is a scary endeavor for most of us because we may feel we lack the skills or training to deal with or delve into what we uncover. There are plenty of ethical considerations as well.

In addition to calling for this type of qualitative approach, we know virtually nothing of the long-term impact of leadership education. How does leadership education help in the long run? Do these students use the information they learn and apply it to their leadership experiences? How does leadership education really impact lives? Where are our students two or ten years down the road? These are the voices of leadership yet to be heard. 


\section{References}

Bass, B. M. (1990). Bass \& Stogdill's handbook of leadership: theory, research, and managerial applications (3rd ed.). New York: The Free Press.

Borwick, D. (1995). No Such Thing as a Leader. The Journal of Leadership Studies 2:103-115.

Brungardt, C. (1996). The Making of Leaders: A review of the research in leadership development and education. The Journal of Leadership Studies 3(3): 81-95.

Buckner, J. K., \& Williams, M. L. (1995). Applying the Competing Values Model of Leadership: Reconceptualizing a university student leadership development program. The Journal of Leadership Studies 2(4):19-34.

Burkhardt, J. C., \& Zimmerman-Oster, K. (2000). Leadership in the making: Impact and insights from leadership development programs in U.S. colleges and universities. Battle Creek, MI: W. K. Kellogg Foundation.

Burns, J. M. (1978). Leadership. New York: Harper \& Row.

Cashman, K. (1999). Leadership from the Inside Out. Provo, UT: Executive Excellence Publishing.

Chemers, M. M. (1993). An Integrative Theory of Leadership. In M. M. Chemers \& R. Ayman (Eds.), Leadership Theory and Research (pp. 293-319). San Diego: Academic Press, Inc.

Cox, C. J., \& Cooper, C. L. (1989). The Making of the British CEO: Childhood, work experience, personality, and management style. Academy of Management Executive 3: 241-245.

DePree, M. (1992). Leadership Jazz. New York: Dell Publishing.

Hartman, S. J., \& Harris, O. J. (1992). The Role of Parental Influence on Leadership. Journal of Social Psychology 132(2):153-167.

Klonsky, B. G. (1987). The socialization and development of leadership ability and responsibility in female adolescents: A multi-ethnic analysis. Unpublished manuscript.

Kouzes, J. M., \& Posner, B. Z. (1995). The Leadership Challenge. San Francisco: Jossey-Bass. 
Lowe, K. B., \& Gardner, W. L. (2001). Ten Years of The Leadership Quarterly: Contributions and challenges for the future. Leadership Quarterly 11(4):459-514.

Rost, J. C., \& Barker, R. A. (2000). Leadership Education in Colleges: Toward a 21st Century Paradigm. The Journal of Leadership Studies, 7(1):3-12.

Sosik, J. J. (2000). Meaning From Within: Possible selves and personal meaning of charismatic and non-charismatic leaders. The Journal Of Leadership Studies $7(2): 3-17$.

Wheatley, M. J. (1990). Leadership and the New Science: Discovering order in a chaotic world. San Francisco: Berrett-Koehler Publishers.

Zacharatos, A., Barling, J., \& Kelloway, E. K. (2000). Development and Effects of Transformational Leadership in Adolescents. Leadership Quarterly 11(2):211226. 